\title{
Perlunya Amandemen Terhadap Pasal 24 B Ayat (1) UUD 1945 Dalam Rangka Pengawasan Terhadap Hakim Konstitusi
}

\author{
Suparto \\ Universitas Islam Riau \\ Jl. Kaharuddin Nst No.113, Simpang Tiga, Kec. Bukit Raya, Kota Pekanbaru, Riau 28284 \\ Email : suparto@law.uir.ac.id
}

\begin{abstract}
Abstrak
Peran dari hakim konstitusi untuk menegakkan keadilan sangat strategis, oleh karena itu diperlukan hakim yang mempunyai sikap dan perilaku yang baik. Dengan demikian hakim konstitusipun perlu dilakukan pengawasan terhadap perilakunya demi menjaga marwah institusi peradilan. Permasalahannya apa upaya yang dapat dilakukan agar pengawasan eksternal terhadap kode etik dan perilaku hakim konstitusi dilaksanakan oleh Komisi Yudisial. Pengawasan yang bersifat eksternal terhadap hakim konstitusi saat ini belum ada pengaturannya, sehingga dimasa mendatang perlu dilakukan karena secara profesi hakim konstitusi sama dengan hakim-hakim yang lain. Komisi Yudisial sebagai lembaga negara hasil reformasi dan diberi kewenangan oleh UUD 1945 untuk menjaga dan menegakkan kehormatan, keluhuran martabat dan perilaku hakim sudah selayaknya untuk diberikan kewenangan untuk melakukan pengawasan eksternal terhadap perilaku hakim konstitusi. Namun demikian pengawasan terhadap hakim konstitusi jangan sampai mengintervensi independensi peradilan sehingga perlu dicarikan formulasi yang tepat untuk mensinergikan antara pengawasan dengan independensi peradilan. Berhubung Pasal 24B ayat (1) terkait kata "hakim" ditafsirkan oleh Mahkamah Konstitusi bukan termasuk hakim konstitusi (Putusan Mahkamah Konstitusi No. 005/PUU-IV/2006 dan No.1-2/PUU-XII/2014, maka ke depan agar hakim konstitusi dapat diawasi oleh Komisi Yudisial, perlu dilakukan amandemen terhadap Pasal 24B ayat (1) UUD 1945 terkait dengan kata "hakim".
\end{abstract}

Kata Kunci : Pengawasan, Hakim Konstitusi, Amandemen UUD 1945

\begin{abstract}
The role of constitutional justices to uphold justice is very strategic, therefore judges who have good attitudes and behavior are needed. Thus, constitutional judges also need to supervise their behavior in order to maintain the dignity of judicial institutions. The problem is what efforts can be made so that external supervision of the code of ethics and behavior of constitutional justices is carried out by the Judicial Commission. External supervision of constitutional judges at this time has not yet been regulated, so that in the future it needs to be done because professionally constitutional justices are the same as other judges. The Judicial Commission as a state institution as a result of reforms and given the authority of the 1945 Constitution to maintain and uphold the honor, nobility and behavior of judges should be given the authority to conduct external supervision of the behavior of constitutional justices. However, the supervision of constitutional justices should not intervene in the independence of the judiciary so that an appropriate formulation is needed to synergize between supervision and judicial independence. Since Article $24 B$ paragraph (1) related to the word "judge" was interpreted by the
\end{abstract}


Constitutional Court not including constitutional justices (Decision of the Constitutional Court No. 005 / PUU-IV / 2006 and No.1-2 / PUU-XII / 2014, then in the future so that Constitutional judges can be supervised by the Judicial Commission, amendments to Article 24B paragraph (1) of the 1945 Constitution are needed in connection with the word "judge".

Keywords: Supervision, Constitutional Justice, Amendment to the 1945 Constitution

\section{A. PENDAHULUAN}

Negara demokrasi tidak hanya mempersyaratkan terjaminnya kebebasan sipil dan politik melainkan meniscayakan juga praktek penegakan hukum yang fair, jelas dan tegas. Tanpa itu, rasanya demokrasi hanya akan menjadi proyek liberalisasi politik yang minim dampak, utamanya bagi peningkatan kesejahteraan masyarakat dan kemajuan negara ini. Sebab, dalam negara demokrasi, lembaga peradilan merupakan instrumen demokrasi yang semestinya bisa diambil manfaatnya oleh masyarakat dalam memperoleh jaminan perlindungan terhadap kebebasan sipil maupun politik. Agar dapat memberi manfaat lembaga peradilan tak boleh menutup diri terhadap demokratisasi.

Kekuasaan kehakiman yang merdeka (independency of judiciary) merupakan syarat mutlak (conditio sine quanon) tegaknya hukum dan keadilan dan harus mendapat jaminan konstitusional yang kuat, sehingga hakim bebas dari pengaruh, bujukan, tekanan, ancaman atau gangguan secara langsung atau tidak langsung dalam melaksanakan tugas dan kewenangan peradilan. Sebagai "nyawa" yang menggerakkan syaraf-syaraf keadilan hakim, independensi adalah juga paradigma, sikap, etos dan etika sehingga keseluruhan totalitas fisik dan non fisik hakim sebagai wakil Tuhan penegak keadilan dimuka bumi memiliki legalitas moral, sosial dan spiritual.

Pentingnya independensi peradilan dijamin oleh negara, hal ini terlihat dalam pernyataan Basic Principles on The Independence of The Judiciary, menegaskan bahwa independensi kekuasaan kehakiman (peradilan) harus ditetapkan dalam konstitusi atau undang-undang negara, dan menjadi tugas pemerintah serta lembaga-lembaga lainnya untuk menghormati dan menjaganya. Independensi kekuasaan kehakiman tidak otomatis terjadi begitu saja, atau bisa diadakan sendiri oleh kekuasaan lembaga peradilan, tetapi membutuhkan peran dari legislatif dan eksekutif, sekalipun peran kekuasaan lain itu laksana pisau bermata dua. Di satu sisi dapat membentuk dan memodifikasi independensi peradilan, tapi di sisi lain berpeluang melakukan campur tangan (intervensi) yang mengakibatkan tersanderanya penerapan independensi peradilan.

Dengan demikian kekuasaan kehakiman yang merdeka itu tidak 'bebas nilai', atau merupakan entitas yang hampa dari berbagai pengaruh dan kepentingan, lebih dari itu, kemerdekaan itu sendiri berada dalam alam misterius pikiran dan hati nurani hakim. Itu sebabnya, hakim menjadi kekuatan sentral dalam menjalankan kekuasaan kehakiman yang independen, dan karena itu pula menjadi penanggungjawab utama dalam mempertahankan dan meningkatkan kepercayaan masyarakat terhadap sistem, moral dan integritas lembaga peradilan. 
Karena ujung tombak lembaga peradilan adalah hakim termasuk didalamnya hakim konstitusi maka kualitas hakim menjadi sangat menentukan bagaimana peran lembaga peradilan secara keseluruhan dalam mewujudkan praktek penegakan hukum yang mengedepankan aspek keadilan. Untuk mendukung hal tersebut, dibutuhkan mekanisme yang tepat dalam rangka menjaga dan mengawal hakim agar tetap on the track menjalankan fungsi lembaga peradilan, sehingga menjadi instrumen demokrasi yang benar-benar bermanfaat bagi rakyat. Agar tetap on the track, maka hakim, hakim agung dan hakim konstitusi perlu diawasi, baik melalui mekanisme internal maupun eksternal. Pada awalnya melalui UU No.22 Tahun 2004, hakim konstitusi secara eksternal diawasi oleh Komisi Yudisial (KY), namun melalui putusan No. 05/PUU-IV/2006 Mahkamah Konstitusi (MK) membatalkan kewenangan KY untuk mengawasi kode etik dan perilaku hakim konstitusi.

Putusan Judicial review MK pada agustus 2006 tentang UU No. 22 Tahun 2004 itu memang agak kompromistis tetapi juga dapat dipersoalkan karena selain dianggap mengandung Ultra Petita juga bertentangan dengan asas nemo judex in causa sua dan sekaligus juga tidak sesuai dengan konsepsi hakim yang dimaksud dalam UUD $1945 .{ }^{1}$

Ketika materi tentang pengawasan hakim konstitusi dilakukan oleh KY diadopsi kembali didalam UU No.4 Tahun 2014, MK kembali lagi membatalkannya melalui putusan No. 1-2/PUU-XII/2014. Berdasarkan uraian tersebut, maka dalam tulisan ini akan bahas Bagaimana pengawasan terhadap kode etik dan perilaku hakim konstitusi serta apa upaya yang dapat dilakukan agar hakim konstitusi secara eksternal dapat diawasi oleh KY.

\section{B. HASIL DAN PEMBAHASAN}

\section{Pelaksanaan Pengawasan Internal Terhadap Kode Etik dan Perilaku Hakim} Konstitusi

Terkait dengan pengawasan perilaku dan etika terhadap hakim Mahkamah Konstitusi pada saat ini Mahkamah Konstitusi telah memiliki dan menerapkan mekanisme pengawasan internal melalui pemberlakuan kode etik. Dalam menjalankan tugas dan fungsinya, hakim konstitusi bekerja dalam koridor kode etik yang telah disepakati dan dituangkan dalam Peraturan Mahkamah Konstitusi No. 9/PMK/2006 tentang Pemberlakuan Deklarasi Kode Etik dan Perilaku Hakim Konstitusi, Peraturan Mahkamah Konstitusi No. 10/PMK/2006 tentang Majelis Kehormatan Mahkamah Konstitusi dan Peraturan Mahkamah Konstitusi No. 3 Tahun 2014 Tentang Majelis Kehormatan Mahkamah Konstitusi. Selain adanya Majelis Kehormatan Hakim, Mahkamah Konstitusi berdasarkan Peraturan Mahkamah Konstitusi No. 2 Tahun 2013 secara internal juga membentuk Dewan Etik. Dugaan pelanggaran terhadap kode etik hakim konstitusi akan diproses sendiri di internal Mahkamah Konstitusi, sesuai dengan Peraturan Mahkamah Konstitusi tersebut. Proses pemeriksaan dilakukan oleh Panel Etik, yang dibentuk untuk memeriksa dugaan pelanggaran etik tersebut.

${ }^{1}$ Aryanto, J. (2012). Pengawasan Hakim Agung dan Hakim Konstitusi oleh Komisi Yudisial, Jurnal Hukum ADIL, Vol.3 (No.2), h.310. 
Panel etik akan memeriksa hakim konstitusi yang diduga melakukan pelanggaran etik dan terdiri atas 3 (tiga) orang hakim konstitusi. Berdasarkan hasil pemeriksaan terhadap hakim yang bersangkutan, Panel Etik akan merekomendasikan kepada Mahkamah Konstitusi, apakah hakim yang diduga melakukan pelanggaran etik itu benar-benar melakukan pelanggaran yang diduga. Kalau memang tidak terbukti dugaan pelanggaran tersebut maka Panel Etik akan merekomendasikan bahwa kepada hakim yang bersangkutan perlu dipulihkan nama baiknya. Akan tetapi, kalau perlu penjatuhan sanksi, Panel Etik dapat merekomendasikan pembentukan Majelis Kehormatan Hakim (MKH). Majelis inilah yang akan memeriksa hakim yang diduga melanggar kode etik, sampai dengan merekomendasikan bentuk sanksinya jika ditemukan bukti-bukti pelanggaran.

Undang-Undang No.8 Tahun 2011 tentang Perubahan Atas Undang-Undang No. 24 Tahun 2003 tentang Mahkamah Konstitusi pada Pasal 27A ayat 2 menyebutkan : Untuk menegakkan Kode Etik dan Pedoman Perilaku Hakim Konstitusi, dibentuk Majelis Kehormatan Mahkamah Konstitusi yang keanggotaannya terdiri atas :
a. 1 (satu) orang Hakim Konstitusi
b. 1 (satu) orang anggota Komisi Yudisial
c. 1 (satu) orang dari unsur DPR
d. 1 (satu) orang dari unsur pemerintah yang menyelenggarakan urusan pemerintahan di bidang hukum, dan
e. 1 (satu) orang Hakim Agung

Majelis Kehormatan Hakim (MKH) berwenang memeriksa hakim yang diduga melakukan pelanggaran etik dan juga meminta keterangan pihak-pihak yang dinilai perlu didengarkan penjelasan dan keterangannya terkait dengan dugaan yang sedang diperiksa. Muara dari MKH soal penjatuhan sanksi jika terbukti bersalah, dan rehabilitasi terhadap hakim yang bersangkutan jika terbukti tidak ada pelanggaran kode etik.

Penulis berpendapat meskipun Komisi Yudisial hanya sebagai anggota dari Majelis Kehormatan Mahkamah Konsitusi hal tersebut merupakan hasil optimal yang dapat dilakukan karena sejak putusan Mahkamah Konstitusi Nomor 005/PUU-IV/2006, Komisi Yudisial tidak dapat melakukan pengawasan terhadap Hakim Konstitusi.

Dikeluarkannya Perpu No.1 Tahun 2013 Tentang Perubahan Kedua atas UndangUndang No. 24 Tahun 2003 Tentang Mahkamah Konstitusi pada awalnya merupakan sebuah langkah yang tepat untuk mengembalikan kepercayaan masyarakat terhadap lembaga peradilan konstitusi ini. Lembaga peradilan konstitusi ini terpuruk setelah ditangkapnya ketua MK nonaktif, Akil Mochtar oleh Komisi Pemberantasan Korupsi [KPK] dalam kasus suap penanganan sengketa pemilihan kepala daerah [Pilkada] Kabupaten Lebak, Banten dan Kabupaten Gunung Mas, Kalimantan Tengah. Namun setelah Perpu MK ditandatangani Presiden Susilo Bambang Yudhoyono justru timbul pro dan kontra, terutama terhadap poin pengawasan hakim MK oleh KY.²

2 Malik. (2013). Perppu Pengawasan Hakim Mahkamah Konstitusi Versus Putusan Final Mahkamah Konstitusi, Jurnal Konstitusi, Vol. 10 (No. 4), h.592. 
Setelah Perpu No. 1 Tahun 2013 yang kemudian menjadi Undang-Undang No. 4 Tahun 2014 dibatalkan oleh Mahkamah Konstitusi dan salahsatu materinya adalah pengawasan terhadap hakim konstitusi oleh KY, maka pengawasan terhadap kode etik dan perilaku hakim Mahkamah Konstitusi kembali mengacu kepada Undang-Undang No. 8 Tahun 2011 yaitu melalui Majelis Kehormatan Hakim Mahkamah Konstitusi dan bersifat ad.hoc. Selain itu Mahkamah Konstitusi juga membentuk Dewan Etik Hakim Konstitusi yaitu melalui Peraturan Mahkamah Konstitusi No. 2 Tahun 2013. Adapun tugas dari Dewan Etik adalah

(1) Menjaga dan menegakkan kehormatan, keluhuran martabat dan perilaku hakim, serta Kode Etik dan Pedoman Perilaku Hakim Konstitusi, supaya Hakim tidak melakukan pelanggaran.

(2) Pelanggaran sebagaimana dimaksud adalah :

a. Melakukan perbuatan tercela

b. Tidak menghadiri persidangan yang menjadi tugas dan kewajibannya selama 5(lima) kali berturut-turut tanpa alasan yang sah

c. Melanggar sumpah atau janji jabatan

d. Dengan sengaja menghambat Mahkamah memberi putusan dalam waktu 90 (sembilan puluh) hari sebagaimana dimaksud dalam Pasal 7B ayat (4) UUD 1945

e. Melanggar Kode Etik dan Pedoman Perilaku Hakim Konstitusi

f. Melanggar larangan sebagai Hakim untuk :

1). Merangkap jabatan sebagai pejabat negara lainnya, anggota partai politik, pengusaha, advokat, atau pegawai negeri

2). Menerima sesuatu pemberian atau janji dari pihak yang berperkara, baik langsung, dan atau

3). Mengeluarkan pendapat atau pernyataan di luar persidangan atas suatu perkara yang sedang ditanganinya mendahului putusan

g. Tidak melaksanakan kewajiban sebagai Hakim untuk :

- Menjalankan hukum acara sebagaimana mestinya

- Memperlakukan para pihak yang berperkara dengan adil, tidak diskriminatif, dan tidak memihak, dan menjatuhkan putusan secara objektif didasarkan pada fakta dan hukum yang dapat dipertanggung jawabkan

(3) Melakukan pengumpulan, pengolahan dan penelaahan laporan dan informasi tentang perilaku Hakim

(4) Memeriksa Hakim Terlapor atau Hakim yang Diduga melakukan pelanggaran

(5) Menyampaikan laporan dan informasi yang telah dikumpulkan, diolah dan ditelaah tentang perilaku Hakim Terlapor atau Hakim yang diduga melakukan pelanggaran

(6) Menyampaikan laporan pelaksanaan tugas secara tertulis setiap bulan kepada Mahkamah.

Apabila berdasarkan pemeriksaan Dewan Etik terbukti bahwa hakim yang bersangkutan melakukan pelanggaran maka Dewan Etik berwenang untuk mengusulkan 
pembentukan Majelis Kehormatan untuk memeriksa dan mengambil keputusan terhadap hakim tersebut.

Sedangkan keanggotaan dan susunan Dewan Etik beranggotakan 3 (tiga) orang, yang terdiri atas :

(1) 1 (satu) orang mantan Hakim Konstitusi

(2) 1 (satu) orang akademisi

(3) 1 (satu) orang tokoh masyarakat

Salahsatu alasan dibentuknya Dewan Etik adalah bahwa kode etik merupakan inti yang melekat yang melekat pada profesi hakim, karena merupakan kode perilaku yang memuat nilai etika dan moral. Kode etik menuntun hakim untuk berintegritas dan profesional. MK mempunyai kode etik dan perilaku Hakim Konstitusi dimaksudkan untuk mengatur perilaku hakim yang diperkenankan, yang dilarang, yang diharuskan, maupun yang dianjurkan atau yang tidak dianjurkan, baik di dalam maupun di luar kedinasan, untuk membentuk hakim sebagai pejabat kekuasaan kehakiman (ambtsgrager van rechtelijkemacht) yang memiliki integritas dan kepribadian yang tidak tercela dan adil untuk dapat menjadi benteng terakhir dalam upaya penegakan hukum dan keadilan. Adanya potensi pelanggaran kode etik dan perilaku oleh Hakim Konstitusi menjadikan pengawasan untuk hakim konstitusi sangat diperlukan oleh karena itu dibentuklah Dewan Etik Hakim Konstitusi yang bersifat permanen. ${ }^{3}$

Pengawasan internal terhadap Hakim Konstitusi yang ada saat ini sebagai mana diatur dalam Peraturan MK No.2 Tahun 2013 Tentang Dewan Etik Hakim Konstitusi, masih memiliki beberapa kekurangan seperti kewenangan pengawasanyang dimiliki oleh Dewan Etik bersifat pasif, hal tersebut dirasa sangatlah longgar mengingat peran Dewan Etik sebagai early warning system, dan keberadaan Dewan Etik yang berada dilingkungan internal MK. ${ }^{4}$

Peraturan MK No.2 Tahun 2013 tentang Dewan Etik Hakim Konstitusi dalam salah satu konsiderannya disebutkan bahwa sebelum terbentuknya Majelis Kehormatan Hakim Konstitusi sebagaimana dimaksud dalam Perpu No. 1 Tahun 2013 perlu dibentuk Dewan Etik Hakim Konstitusi. Dalam peraturan MK tersebut, pembentukan majelis kehormatan diusulkan oleh Dewan Etik Hakim Konstitusi. Hal ini mencerminkan bahwa pengawasan hakim konstitusi dilaksanakan sepenuhnya secara internal oleh MK. ${ }^{5}$

Setelah adanya pembatalan Perpu No. 1 Tahun 2013 atau UU No. 4 Tahun 2014, Mahkamah Konstitusi juga mengeluarkan Peraturan Mahkamah Konstitusi No. 2 Tahun 2014 Tentang Majelis Kehormatan Mahkamah Konstitusi. Peraturan Mahkamah Konstitusi tersebut pada dasarnya sama dengan peraturan Mahkamah Konstitusi sebelumnya yaitu peraturan

\footnotetext{
${ }^{3}$ Mardiya, Nuzul Q. (2017). Pengawasan Perilaku Hakim Mahkamah Konstitusi oleh Dewan Etik, Jurnal Hukum dan Peradilan, Vol.6 (No.1), h.32.

${ }^{4}$ Aulia, E., et. al. (2015). Pengawasan Hakim Konstitusi dalam Mewujudkan Independensi Hakim, Jurnal Ilmu Hukum Pascasarjana Unsyiah, Vol.3 (No.2), h.51.

${ }^{5}$ Nababan, Budi S.P. \& Iswahyudi, F. (2014). Pengawasan Hakim Konstitusi Setelah Putusan Mahkamah Konstitusi No.1-2/PUU-XII/2014, Jurnal Legislasi, Vol.11 (No. 2), h.158.
} 
Mahkamah Konstitusi No. 10/PMK/2006, yang membedakannya adalah keanggotaan dari Majelis Kehormatan Hakim Mahkamah Konstitusi tersebut yaitu terdiri dari :
a. $\quad 1$ (satu) orang Hakim Konstitusi
b. 1 (satu) orang Komisi Yudisial
c. $\quad 1$ (satu) orang mantan Hakim Konstitusi
d. 1 (satu) orang Guru Besar dalam bidang Hukum
e. 1 (satu) orang tokoh masyarakat.

Mekanisme pengawasan hakim konstitusi yang hanya mengadopsi Majelis Kehormatan Hakim Konstitusi, memiliki kelemahan jika dibandingkan dengan mekanisme pengawasan hakim menurut UUD NRI 1945, karena mekanisme pengawasan hakim pada dasarnya melibatkan lembaga diluar struktur organisasi. Lembaga pengawas hakim yang mandiri dan bebas dari campur tangan lain mutlak diperlukan dalam rangka menegakkan kehormatan, menjaga keluhuran martabat serta perilaku hakim untuk mewujudkan pemerintahan yang baik dan bersih. ${ }^{6}$

\section{Perlunya Pengawasan Eksternal Terhadap Kode Etik dan Perilaku Hakim Konstitusi}

Untuk menjaga marwah lembaga peradilan, idealnya Mahkamah Konstitusi memerlukan pengawasan, baik itu pengawasan internal maupun pengawasan eksternal. Membiarkan Mahkamah Konstitusi berjalan tanpa mekanisme pengawasan sebenarnya cukup membahayakan bagi Mahkamah Konstitusi itu sendiri. Sekalipun Mahkamah Konstitusi dengan hakim-hakim yang ada sekarang ini, merasa sudah cukup diawasi oleh masyarakat, baik melalui media massa, LSM maupun kalangan kampus, akan tetapi itu masih sangat menggantungkan pada pengawasan spontan (tak terprogram), kualitas orang perorangan, dan bukan pada sistem. Mungkin dengan hakim konstitusi yang ada sekarang, dengan integritasnya yang tinggi, seolah-olah hakim konstitusi tak memerlukan pengawasan lagi. Sebab, mekanisme informal yang diciptakan di dalam telah membuat hakim berada pada situasi saling mengawasi. Itu sebabnya, hampir tak ada peluang dan bahkan mungkin tak pernah terpikirkan oleh hakim yang ada sekarang untuk bermain-main, selain karena integritas juga karena adanya mekanisme saling mengawasi semacam itu. ${ }^{7}$

Dalam memformulasi sistem pengawasan terhadap hakim Mahkamah Konstitusi, dibutuhkan racikan yang tepat antara kewenangan pengawasan hakim dengan prinsip independensi hakim. Kegagalan-kegagalan terdahulu terjadi karena pengawas hakim sering tidak puas untuk sekedar mengawasi perilaku hakim sehingga kerap ngotot ingin masuk ke ranah putusan hakim. Komisi Yudisial misalnya, sebagai lembaga negara pelaku pengawasan eksternal terhadap kode etik dan perilaku hakim mengaku mengalami kesulitan melaksanakan kewenangan mengawasi perilaku hakim tanpa membaca putusan hakim.

6 Tutik, T.T. (2012). Pengawasan Hakim Konstitusi dalam Sistem Pengawasan Hakim Menurut UUD RI 1945, Jurnal Dinamika Hukum, Vol.12 (No.2), h.308.

7 Mahfud MD, M. (2011). Membangun Sistem Pengawasan Dan Meneguhkan Independensi Hakim Konstitusi, Makalah Seminar Kerjasama FH UII dengan Hans Seidel Foundation (HSF), Yogyakarta. 
Sebab, hampir semua laporan yang diterima Komisi Yudisial ditengarai berkaitan langsung dengan putusan hakim, yang artinya berada pada teknis yudisial. Oleh sebab itu, dalam hal pengawasan hakim kerapkali menuntut Komisi Yudisial membaca vonis pengadilan untuk kemudian memanggil hakim yang memutus vonis itu untuk diperiksa. Sebab dalam banyak kasus memang tak mungkin menghindar dari keharusan membaca vonis untuk menentukan pelanggaran yang dilakukan oleh hakim. Alasannya, setiap kolusi itu pasti bermuara ke dalam vonis. $^{8}$

Mengenai independensi Kekuasaan Kehakiman, termasuk Mahkamah Konstitusi, Pasal 24 ayat (1) UUD 1945 hasil perubahan menyatakan Kekuasaan Kehakiman merupakan kekuasaan yang merdeka untuk menyelenggarakan peradilan guna menegakkan hukum dan keadilan. Ketentuan tersebut menjelaskan sifat dan tujuan dari penyelenggaraan kekuasaan kehakiman, yaitu kekuasaan yang merdeka guna menegakkan hukum serta keadilan. Disamping itu, frasa "kekuasaan yang merdeka" memperlihatkan dan sekaligus menegaskan bahwa kekuasaan kehakiman adalah kekuasaan yang terpisah dari cabang kekuasaan lainnya dan dalam melaksanakan fungsinya itu tak dapat dipengaruhi oleh pihak manapun.

Oleh sebab itu dengan sifat independen yang dimiliki, maka pengawasan yang dimaksud mestinya bukanlah pengawasan terhadap Mahkamah Konstitusi sebagai Institusi, karena kekuasaan yang "merdeka" itu menimbulkan konsekuensi bahwa Mahkamah Konstitusi tak dapat dan tak boleh diawasi oleh lembaga lain. Pengawasan mestinya lebih tertuju kepada hakim konstitusi sebagai individu-individu terkait dengan perilaku dan etikanya. ${ }^{9}$

Terkait dengan pengawasan terhadap hakim termasuk hakim konstitusi, perlu ditelaah tentang pengawasan itu sendiri. Substansi dari pengawasan bahwa pengawasan atau kontrol sejatinya adalah mekanisme normal, positif dan konstitusional dalam negara hukum dan negara demokratis agar kekuasaan politik atau kekuasaan hukum tidak menyimpang atau disalahgunakan baik secara sengaja, tidak sengaja atau karena kelalaian, sehingga disediakanlah norma atau institusi pengujian, kontrol atau verifikasi. Pengawasan Hakim Mahkamah Konstitusi diperlukan dengan alasan :

1. Pengawasan dibutuhkan dalam mengontrol jalannya sistem peradilan di Indonesia (yudikatif). Pengawasan terhadap lembaga peradilan lebih menitikberatkan pada pengawasan terhadap hakim, tidak terkecuali hakim konstitusi.

2. Isu dan kasus yang menerpa dua hakim Mahkamah Konstitusi yang berujung mundurnya salah seorang diantaranya, seolah menjadi pembenaran adanya kekhawatiran, bahwa independensi, imparsialitas, integritas, dan kompetensi hakim-hakim Mahkamah Konstitusi akan menurun secara signifikan yang pada gilirannya membuat Mahkamah Konstitusi kehilangan kepercayaan.

8 Ibid.
${ }^{8}$ Ibid. 
3. Menjaga dan menegakkan citra Mahkamah Konstitusi yang sampai saat ini masih dipercaya publik sebagai satu-satunya peradilan yang relatif menjalankan proses peradilan dengan memenuhi prinsip-prinsip ideal peradilan. ${ }^{10}$

Kekuasaan kehakiman merupakan kekuasaan negara yang merdeka atau independen, oleh karena itu tidak boleh ada intervensi dari pihak manapun dalam menjalankan tugas dan kewenangannya. Di sisi lain hakim adalah manusia biasa yang dapat saja berbuat khilaf atau bahkan sengaja melakukan hal-hal yang menyimpang dengan berlindung di balik independensi. Berkaitan dengan hal tersebut kedepan harus dilakukan penguatan terhadap tugas dan kewenangan Komisi Yudisial sebagai lembaga negara pelaku pengawasan terhadap hakim serta perlu dicarikan formulasi yang tepat agar pelaksanaan pengawasan tidak mengganggu atau berbenturan dengan independensi Kekuasaan Kehakiman.

Terkait dengan pengawasan eksternal terhadap hakim Mahkamah Konstitusi, Moh. Mahfud MD, sepakat bahwa kedepan hakim Mahkamah Konstitusi harus diawasi untuk kepentingan Mahkamah Konstitusi dalam jangka panjang. Pengawasan terhadap hakim Mahkamah Konstitusi menurut Mahfud tidak didasari atas kecurigaan pada hakim Mahkamah Konstitusi, tetapi untuk menjaga martabat dan kehormatan Mahkamah Konstitusi. ${ }^{11}$

Semangat atau spirit dari berbagai pendapat yang belakangan ini muncul sekalipun ada yang tidak setuju, maka Hakim Mahkamah Konstitusi tidak mungkin tidak diawasi. Kekuasaan kehakiman dengan keputusan yang final dan mengikat artinya tidak ada upaya hukum lagi, adalah kekuasaan konstitusional absolut yang punya peluang salah, tidak adil, tidak fair, tidak objektif, tidak profesional. Hakim-Hakim Mahkamah Konstitusi juga punya peluang untuk melakukan kesalahan sengaja ataupun kelalaian manusiawi (Marzuki, 2011).12

Berdasarkan berbagai alasan tersebut, ditambah situasi hukum dan penegakan hukum saat ini yang sedang dilanda ketidakpercayaan oleh masyarakat, serta untuk meletakkan Mahkamah Konstitusi sebagai penjaga konstitusi, maka DPR, Pemerintah dan Mahkamah Konstitusi harus menerjemahkan nilai-nilai, asas-asas dan imparsialitas serta akuntabilitas Hakim Mahkamah Konstitusi.

Meskipun terdapat penolakan terhadap adanya campur tangan lembaga non yudisial (extra judical) dalam pengawasan hakim konstitusi, tetapi telah menjadi pilihan politik hukum yang permanen bahwa dalam rangka menjaga dan menegakkan kehormatan, keluhuran martabat, serta perilaku hakim diperlukan pengawasan terhadap perilaku hakim agar sesuai kode etik dan pedoman perilaku sehingga setiap putusan hakim dilaksanakan dalam rangka

${ }^{10}$ Suparman, E. (2011). Pentingnya Pengawasan Hakim Konstitusi Oleh Komisi Yudisial, Makalah Seminar Fakultas Syariah dan Ilmu Hukum UIN Sultan Syarif Kasim, Pekanbaru

11 Mahfud MD, M. (2011). Op.cit. h.78

12 Marzuki, S. (2011). Pengawasan Hakim Untuk Pengadilan Yang Bersih, Makalah dalam Seminar Pemerkuatan Pemahaman Hak Asasi Manusia Untuk Hakim Seluruh Indonesia, Kerjasama Komisi Yudisial dengan PUSHAM UII, Yogyakarta. 
menegakkan hukum dan keadilan berdasarkan pancasila dan UUD Tahun 1945 (Muhtadi, 2015 : 318).13

Oleh karena itu pengawasan terhadap hakim konstitusi menurut penulis mutlak untuk dilakukan, karena tidak boleh ada satu lembaga negarapun yang bebas dari pengawasan. Hal ini merupakan bentuk transparansi dan pertanggungjawaban kepada publik yang juga merupakan tuntutan bagi lembaga-lembaga negara dinegara modern saat ini. Secara profesi, hakim konstitusi adalah juga sama dengan hakim negeri, hakim tinggi, hakim agung dan juga hakim-hakim yang lain. Jadi tidak boleh ada diskriminasi perlakuan termasuk dalam hal pengawasan.

Dilihat dari sifat putusan Mahkamah Konstitusi yang final dan binding, maka dapat dijelaskan bahwa putusan Mahkamah Konstitusi sangat absolut artinya putusannya bersifat terakhir dan mengikat serta tidak ada lagi upaya hukum yang dapat dilakukan. Walaupun Hakim Konstitusi merupakan orang-orang pilihan dengan seleksi yang ketat tetapi Hakim Konstitusi tetaplah manusia yang punya peluang untuk berbuat salah dan khilaf. Apalagi kalau Hakim Konstitusi itu melakukan tindakan-tindakan yang sengaja menyimpang dan berlindung dibalik putusan yang bersifat final dan mengikat tersebut.

Dilihat dari kewenangan Mahkamah Konstitusi (4 kewenangan dan 1 kewajiban) yang diamanatkan oleh UUD 1945 yaitu : Pasal 24C ayat (1) dan (2) Undang-Undang Dasar 1945 berbunyi :

1. Mahkamah Konstitusi berwenang mengadili pada tingkat pertama dan terakhir yang putusannya bersifat final untuk menguji undang-undang terhadap UndangUndang Dasar, memutus sengketa kewenangan lembaga negara yang kewenangannya diberikan oleh Undang-Undang Dasar, memutus pembubaran partai politik, dan memutus perselisihan tentang hasil pemilihan umum.

2. Mahkamah Konstitusi wajib memberikan putusan atas pendapat Dewan Perwakilan Rakyat mengenai dugaan pelanggaran oleh Presiden dan/atau Wakil Presiden menurut Undang-Undang Dasar.

Ditambah lagi pada saat ini penyelesaian sengketa hasil pemilukada juga masuk kedalam kewenangan Mahkamah Konstitusi. Kalau diamati, kewenangan-kewenangan tersebut sangat strategis dan menentukan serta menimbulkan implikasi yang sangat luas oleh karena itu para pihak yang berperkara di Mahkamah Konstitusi akan menggunakan segala daya upaya baik itu kekuatan politik, kekuatan uang/modal maupun kekuatan sosial, untuk mencapai tujuannya.

Sebagai salah satu contoh adalah dalam kasus korupsi yang dialami oleh mantan ketua Mahkamah Konstitusi Akil Mochtar, terungkap fakta dalam persidangan bahwa karena tidak adanya pengawasan terhadap perilakunya, Akil Mochtar bisa bebas bepergian ke luar negeri (Singapura) untuk bertemu Ratu Atut Choisiyah (mantan Gubernuar Banten) dan bertemu dengan Habit Binti (mantan Bupati Gunung Mas) di rumah dinasnya, demikian juga dengan

13 Muhtadi. (2015). Politik Hukum Pengawasan Hakim Konstitusi, Jurnal Ilmu Hukum Fiat Justisia, Vol. 9 (No.3), h.318. 
mantan hakim konstitusi Patrialis Akbar, yang acapkali bertemu dengan pihak yang sedang melakukan pengujian UU di MK, padahal seorang hakim dilarang bertemu dengan pihak-pihak yang diduga terkait dengan penanganan perkara yang ditangani.

Dari uraian-uraian tersebut menurut penulis tidak ada alasan untuk tidak melakukan pengawasan terhadap Hakim Konstitusi seperti halnya dengan hakim-hakim yang lain. Dan sudah selayaknya pengawasan eksternal terhadap hakim konstitusi tersebut dilakukan oleh Komisi Yudisial sebagai lembaga negara konstitusi (constitutional organ) yang mempunyai kewenangan untuk mengawasi perilaku hakim.

Setelah perubahan UUD 1945 tidak ada satupun lembaga negara yang memegang kekuasaan tak terbatas tak terkecuali Mahkamah Agung dan Mahkamah Konstitusi sebagai lembaga yang melaksanakan Kekuasaan Kehakiman. Keberadaan Komisi Yudisial dimaksudkan antara lain sebagai salah satu lembaga yang dapat mengimbangi dan mengontrol kiprah para hakim, termasuk Hakim agung dan Hakim Konstitusi. Aturan main lebih rinci mengenai pelaksanaan kewenangan Komisi Yudisial menjadi mutlak diperlukan agar tak menimbulkan sengketa antar lembaga negara. Aturan main itu harus berada dalam wadah undang-undang agar memiliki kekuatan hukum dan menjadi acuan hukum bersama.

Komisi Yudisial merupakan bagian dari kekuasaan kehakiman yang ditujukan untuk memperkuat checks and balances dari kekuasaan kehakiman yang merdeka, sekaligus penunjang pelaksanaan fungsi dan kewenangan badan kekuasaan kehakiman itu sendiri. Pembentukan Komisi Yudisial bukanlah sekedar mengikuti kecenderungan (trend) yang terjadi di banyak negara, tetapi suatu keniscayaan dalam reformasi peradilan dan konstitusi. Bahkan embrio gagasannya sudah lama muncul sebagai bagian dari upaya menjaga dan meningkatkan integritas hakim dan sistem peradilan. Dengan kata lain, Komisi Yudisial turut berperan serta dalam memiliki tanggungjawab untuk mengupayakan tercapainya kondisi ideal dari fungsi dan kewenangan lembaga peradilan yang mandiri. Komisi Yudisial merupakan bentuk dari konsep pertanggungjawaban yang diperlukan untuk menunjang independensi peradilan itu.

Masih terkait dengan fungsi pengawasan, misi utama reformasi peradilan tidak hanya sebatas menegakkan independensi dan imparsialitas peradilan. Tetapi juga membangun dan menjaga sistem akuntabilitas serta mekanisme kontrol bagi para hakim termasuk hakim konstitusi agar peradilan tidak memunculkan abuse of power atau tyrani judicial. Dalam konteks ini maka dalam menjalankan fungsi pengawasan, Komisi Yudisial harus mencari titik konvergensi/titik singgung antara independensi versus akuntabilitas, mengawasi tanpa mengganggu independensi.

Komisi Yudisial sesungguhnya merupakan mitra strategis dari DPR dan Presiden untuk melakukan dan memperkuat kontrol (checks and balances) terhadap Mahkamah Agung dan Mahkamah Konstitusi. Pembentukan Komisi Yudisial dan juga komisi-komisi independen lainnya adalah dimaksudkan sebagai Institutional Watchdog. Fungsinya adalah untuk memperkuat checks and balances, membangun akuntabilitas dan memperluas partisipasi masyarakat. Melalui kewenangannya, Komisi Yudisial punya peran sinergis bersama DPR dan Presiden untuk mendapatkan calon Hakim agung yang kredibel dan berintegritas. Melalui Komisi Yudisial diharapkan pula harkat, martabat dan perilaku para hakim dapat terjaga, 
tidak terkecuali Hakim Konstitusi, walaupun seleksi atau pencalonan Hakim Konstitusi tidak melalui Komisi Yudisial (Arifin, 2007 : 16). Dan pada akhirnya akan tercipta peradilan yang bersih dan berwibawa serta dipercaya oleh masyarakat sehingga institusi kekuasaan kehakiman menjadi kuat.

\section{PENUTUP}

\section{Kesimpulan}

Kekuasaan Kehakiman merupakan kekuasaan yang mandiri dan bebas dari campur tangan pihak manapun. Hakim merupakan profesi atau jabatan yang sangat mulia dan terhormat. Oleh karena itu perilaku hakim termasuk hakim konstitusi harus dijaga demi menjaga marwah institusi Mahkamah Konstitusi sehingga kedepannya diperlukan adanya pengawasan terhadap kode etik dan perilaku hakim, baik itu yang bersifat internal, maupun eksternal. Namun demikian, pengawasan eksternal terhadap hakim Mahkamah Konstitusi jangan sampai mengganggu independensi hakim Mahkamah Konstitusi. Pengawasan internal terhadap kode etik dan perilaku hakim konstitusi saat ini telah ada yaitu diatur dalam Peraturan Mahkamah Konstitusi Nomor : 09/PMK/2006 tentang Pemberlakuan Deklarasi Kode Etik dan Perilaku Hakim, Peraturan Mahkamah Konstitusi Nomor : 10/PMK/2006 tentang Majelis Kehormatan Mahkamah Konstitusi, Peraturan Mahkamah Konstitusi No. 2 Tahun 2013 tentang Dewan Etik Hakim Konstitusi, Peraturan Mahkamah No. 2 Tahun 2014 tentang Majelis Kehormatan Mahkamah Konstitusi dan Undang-Undang Nomor : 8 Tahun 2011 tentang Perubahan Atas Undang-Undang Nomor : 24 Tahun 2003 tentang Mahkamah Konstitusi.

Pengawasan yang bersifat eksternal terhadap hakim Mahkamah Konstitusi saat ini belum ada pengaturannya. Sehingga dimasa mendatang pengawasan eksternal ini perlu juga dilakukan karena secara profesi hakim konstitusi sama dengan hakim-hakim yang lain termasuk dengan hakim agung. Komisi Yudisial sebagai lembaga negara hasil reformasi dan diberi kewenangan oleh UUD 1945 untuk menjaga dan menegakkan kehormatan, keluhuran martabat dan perilaku hakim sudah selayaknya untuk diberikan kewenangan untuk melakukan pengawasan eksternal terhadap perilaku hakim konstitusi. Karena di zaman demokrasi modern seperti sekarang ini tidak boleh ada lembaga negara ataupun personalnya yang bebas dari pengawasan, hal ini sebagai bentuk dari akuntabilitas dan pelaksanaan dari prinsip check and balances. Namun demikian pengawasan terhadap hakim konstitusi ini jangan sampai mengganggu atau mengintervensi independensi peradilan sehingga perlu dicarikan formulasi yang tepat untuk mensinergikan antara pengawasan dengan independensi peradilan.

\section{Saran}

Berhubung Pasal 24B ayat (1) terkait kata "hakim" ditafsirkan oleh Mahkamah Konstitusi bukan termasuk hakim konstitusi (Putusan Mahkamah Konstitusi No. 005/PUU-IV/2006 dan No.1-2/PUU-XII/2014), maka ke depan agar Komisi Yudisial dapat mengawasi hakim konstitusi, perlu dilakukan amandemen terhadap Pasal 24B ayat (1) UUD 1945 terkait dengan kata "hakim", sehingga selengkapnya berbunyi “ Komisi Yudisial bersifat mandiri yang berwenang mengusulkan pengangkatan hakim agung dan mempunyai wewenang lain dalam 
rangka menjaga dan menegakkan kehormatan, keluhuran martabat serta perilaku hakim, hakim agung dan hakim konstitusi.

\section{Buku}

Arifin, F. (2007). Komisi Yudisial Pengawal Reformasi Peradilan Mendayung Diantara Simpati Dan Resistensi, Bunga Rampai Komisi Yudisial, Edisi ke II, Jakarta : Komisi Yudisial RI.

Mahfud MD, M. (2006). Membangun Politik Hukum, Menegakkan Konstitusi, Jakarta : LP3ES.

\section{Jurnal dan Makalah}

Aulia, E., et. al. (2015). Pengawasan Hakim Konstitusi dalam Mewujudkan Independensi Hakim, Jurnal Ilmu Hukum Pascasarjana Unsyiah, Vol.3 (No.2), pp.46-54.

Aryanto, J. (2012). Pengawasan Hakim Agung dan Hakim Konstitusi oleh Komisi Yudisial, Jurnal Hukum ADIL, Vol.3 (No.2), pp.283-312.

Mahfud MD, M. (2011). Membangun Sistem Pengawasan Dan Meneguhkan Independensi Hakim Konstitusi, Makalah Seminar Kerjasama FH UII dengan Hans Seidel Foundation (HSF), Yogyakarta.

Malik. (2013). Perppu Pengawasan Hakim Mahkamah Konstitusi Versus Putusan Final Mahkamah Konstitusi, Jurnal Konstitusi, Vol. 10 (No. 4), pp. 579-604.

Mardiya, Nuzul Q. (2017). Pengawasan Perilaku Hakim Mahkamah Konstitusi oleh Dewan Etik, Jurnal Hukum dan Peradilan, Vol.6 (No.1), pp.25-40.

Marzuki, S. (2011). Pengawasan Hakim Untuk Pengadilan Yang Bersih, Makalah dalam Seminar Pemerkuatan Pemahaman Hak Asasi Manusia Untuk Hakim Seluruh Indonesia, Kerjasama Komisi Yudisial dengan PUSHAM UII, Yogyakarta.

Muhtadi. (2015). Politik Hukum Pengawasan Hakim Konstitusi, Jurnal Ilmu Hukum Fiat Justisia, Vol. 9 (No.3), pp. 310-330.

Nababan, Budi S.P. \& Iswahyudi, F. (2014). Pengawasan Hakim Konstitusi Setelah Putusan Mahkamah Konstitusi No.1-2/PUU-XII/2014, Jurnal Legislasi, Vol.11 (No. 2), pp. 151160.

Suparman, E. (2011). Pentingnya Pengawasan Hakim Konstitusi Oleh Komisi Yudisial, Makalah Seminar Fakultas Syariah dan Ilmu Hukum UIN Sultan Syarif Kasim, Pekanbaru

Tutik, T.T. (2012). Pengawasan Hakim Konstitusi dalam Sistem Pengawasan Hakim Menurut UUD RI 1945, Jurnal Dinamika Hukum, Vol.12 (No.2), pp. 295-311.

\section{Perundang-undangan dan Peraturan}

Undang-Undang Dasar Republik Indonesia 1945.

Undang-Undang Nomor 24 Tahun 2003 Tentang Mahkamah Konstitusi

Undang-Undang Nomor 8 Tahun 2011 Tentang Perubahan Atas Undang-Undang Nomor 24

Tahun 2003 Tentang Mahkamah Konstitusi 
Undang-Undang Nomor 4 Tahun 2014 Tentang Perubahan Kedua Atas Undang-Undang Nomor 24 Tahun 2003 Tentang Mahkamah Konstitusi

Putusan Mahkamah Konstitusi No. 05/PUU-VI/2006 Tentang Pengujian UU No. 22 Tentang Komisi Yudisial

Putusan Mahkamah Konstitusi No. 1-2/PUU-XII/2014 Tentang Pengujian UU No. 4 Tahun 2014 Tentang Perubahan Kedua Atas UU No. 24 Tahun 2003 Tentang Mahkamah Konstitusi

Peraturan Mahkamah Konstitusi No. 9/PMK/2006 Tentang Pemberlakuan Deklarasi Kode Etik dan Perilaku Hakim Konstitusi.

Peraturan Mahkamah Konstitusi No. 10/PMK/2006 Tentang Majelis Kehormatan Mahkamah Konstitusi.

Peraturan Mahkamah Konstitusi No. 2 Tahun 2013 Tentang Dewan Etik Hakim Konstitusi

Peraturan Mahkamah Konstitusi No. 2 Tahun 2014 Tentang Majelis Kehormatan Mahkamah Konstitusi 